\title{
Viet Nam's Food Security: A Castle of Cards in the Winds of Climate Change
}

\author{
FRANÇOIS FORTIER
}

\begin{abstract}
Since the 1980s, Viet Nam has achieved rapid economic growth and greatly increased food production and security. Those results are based, however, on a model of industrial agriculture that has inherent social and environmental limitations and increasingly faces the structural constraints of climate change. This article questions industrial agriculture, in general and through the case of Viet Nam, and its ability to sustain outputs and food security through the emerging crisis. It argues that while agroindustrial technologies and commodification are making the country particularly vulnerable to the imprecise and shifting context of a multifaceted crisis, the dominant response of the green economy, in Viet Nam as elsewhere, rests on unsubstantiated technological and institutional assumptions. Unchanged, such strategy will most likely lead to the collapse of Vietnamese agricultural production and a surge of food insecurity. In such a strategic vacuum, the article explores how agroecology offers a viable alternative, in parallel with the organization of production, distribution, and consumption through principles of food sovereignty.
\end{abstract}

KEYWORDS. food security · food sovereignty $\cdot$ industrial agriculture $\cdot$ agroecology $\cdot$ Viet Nam $\cdot$ climate change $\cdot$ mitigation and adaptation technologies

\section{INTRODUCTION}

Since the launch of the Vietnamese Doi moi (reform) process in the 1980s under the label of a socialist-oriented market economy, the country has achieved rapid economic growth and increased food production severalfold. The development of agriculture has had significant impacts on national food security, while providing livelihoods to 60 percent of the population and generating about a quarter of Viet Nam's gross domestic product (GDP) (Carew-Reid 2008, 6). This gives, however, a false sense of security, for those achievements are entirely rested on a model of industrial agriculture that has inherent social tensions and mounting contradictions, and which is also now facing structural 
challenges beyond its immediate organization of production, particularly those of climatic instability.

The point of departure of this article is therefore to question the viability of industrial agriculture, in general and through the case of Viet Nam, and the unlikelihood of it being able to sustain outputs and food security through this emerging crisis. This paper argues that, in the context of agricultural modernization, Viet Nam's dependence on technology and commodification is making it particularly vulnerable to the imprecise and shifting context of climate change. The strategic response to this challenge, branded as a green economy in Viet Nam as almost everywhere else, has been to provide technological and institutional remedies that, it is claimed, will decarbonize the economy while intensifying production outputs and maintaining food security amidst a changing climate. However, there is mounting evidence that such fixes will not ensure sustained economic activities, including industrial agriculture and food security. The magnitude of greenhouse gases $(\mathrm{GHG})$ mitigation required and the time frame within which this is needed make virtually impossible the timely development and adoption of innovations that would be necessary but still remain, for the most part, unproven concepts. The article discusses how such strategy would most likely lead to the collapse of Viet Nam's industrial agriculture and the loss of its food sufficiency and security. The situation begs to urgently adopt agroecology, both as a means of ensuring food security and as a key contribution to GHG mitigation, and to restructure production, distribution, and consumption under principles of food sovereignty.

To make this argument, the article first reviews the process of agricultural modernization that has given rise to the current basis of Vietnamese food security, and the emerging biophysical context of climate uncertainty that now threatens agriculture. This leads to considering the response now being articulated by the Vietnamese state, well aligned on global climate governance trends. The article then turns to a critique of this response, examining the unrealistic expectations of hypothetical technological fixes that would address both mitigation of GHG emissions and adaptation of industrial food systems. The critique underlines the fragility of the current model, and its likelihood of collapse under multiple stressors. Beyond the shortcomings and deception of that model, the article concludes that only agroecology, and its organization under principles of food sovereignty, can offer viable alternatives. 


\section{The Rise of Productivity}

From the mid-twentieth century, successive Vietnamese governments made significant investments in the modernization of agriculture. While it started slowly due to the protracted French and American wars, by the 1960s, this modernization had intensified in both North and South Viet Nam, notably with large-scale irrigation and drainage works, some level of mechanization, the introduction of modern highyielding varieties, and the increasing application of agrochemicals (Taylor 2007, 10; ADPC 2003, 15-17).

In the North, the government of the Democratic Republic of Viet Nam was an unwavering believer in the potential of human ingenuity, both in technological and organizational terms. It prioritized agricultural investments, notably in water management, resulting in the increase of irrigated areas of the total agricultural land from 42 percent in 1955 to 64 percent in 1960 (Bhaduri and Rahman 1982, 42). In the first half of the 1960s, the budget allocated to the agricultural sector had increased fivefold compared to the late 1950s, bringing an additional two hundred thousand hectares into production (Ha Vinh 1997, 1046). The state also promoted the use of short-cycle modern high-yielding varieties, enabling multiple production seasons for rice and other crops (Wiegersma 1988, 167). Policies were, however, more reserved with respect to agricultural mechanization. It adopted instead an approach of technical duality, discouraging the use of equipment that could displace large amount of labor while promoting technologies that had less such effect. "The net result was a sparse spread of small farm equipment. In 1977, the northern region had 10,160 tractors, which provided mechanized land preparation for $16 \%$ of the area" (Pingali et al. 1997, 353). Agrochemical inputs were also scarce, for not being produced domestically and their importation constrained by limited financial resources. By the end of the 1970s, however, agrochemical inputs, mostly imported from the Soviet Union, had become more commonly used in the Democratic Republic of Vietnam (DRV) (Fforde and Sénèque 1994, 21).

In the southern Republic of Viet Nam, the process of agricultural modernization was more intensive. Capitalist accumulation had already spread faster there during French colonization (Marquis 2000, 91), and production was largely commercialized by the 1950s. From then until 1975 and with American funds, the South provided testing grounds for the Modernization Theory by its intellectual father Walt Rostow himself (Pearce 2001). "The growth in the use of capital inputs 
in agriculture ... was produced by a massive import of farm equipment, fertilisers and oil which was made possible by US aid money, by an enormous infusion of liquid capital into the hands of the landlords through the so-called 'Land to the Tiller' programme and by substantial loans supplied by the American subsidized Rural Development Bank" (Long 1984, 286). In 1975, high-yielding varieties of rice were planted on between 0.6 million hectares (Pingali et al. 1997, 351) and 1 million hectares of paddy fields, and accounted for about 30 percent of the total paddy output (Young et al. 2002, 10, 14). Between 30 percent and 40 percent of the land in 1977 was being tilled by tractors (Pingali et al. 1997, 353), while large-scale water-control projects were drawn to replicate the hydraulic engineering of the Tennessee valley across the Mekong Delta (Käkönen 2009, 206).

By the end of the American war and in the aftermath of the 1975 reunification, the northern cooperative system slid deeper into crisis, while efforts to collectivize the south failed (Long 1993, 169-73). In 1979, the government started experimenting with economic reforms, which culminated in the official launch of the Doi moi (renovation) policies in 1986. While transforming the organization and relations of production by steering away from collectivization, agricultural market incentives were introduced, upstream and downstream channels were liberalized, and steps were taken to rejoin the global economy (Kerkvliet 1995). The reform reiterated modernizing objectives by embracing the green revolution: it intensified irrigation and agrochemical use, adopted modern varieties, pushed the agricultural frontiers, and reclaimed costal lands (see notably Tran Thi Thu Trang in this issue). Within that period, Viet Nam's agricultural production grew remarkably. While the country produced 16 million tons of rice in 1986, the output reached over twice this figure by 2008 , at 36 million tons. Productivity surged by 86 percent, from 2.6 to 4.9 tons per hectare (IRRI 2009). The largest share of that surplus comes from the Mekong Delta, supplying more than half the increase of the last fifteen years. ${ }^{1}$ As a result, Viet Nam went from being a net importer of rice in the 1980 s to becoming the world's second largest exporter, selling 4-5 million tons per year-that is, $15-20$ percent of the globally traded annual volume (IRRI 2007). The number of food insecure people was also reduced by one-third between 1990 and 2005. Beyond rice, other food outputs also increased, which contributed to some extent in reducing rural poverty. By official accounts, the share of the population living 
under the poverty line decreased from 75 percent in 1988 to 15.5 percent by 2006 .

\section{LOOMING THREATS}

Despite the productivity gains obtained through such an intensive modernization of agriculture, the actual magnitude of the benefits, the spread of their impact among different groups and regions, and their hidden social and environmental costs are not unchallenged (see notably Kolko 1997, 104-6; Pincus and Sender 2008; Trang 2009, 2010). There has also been growing concerns with respect to national food production over the coming years, which could threaten whatever actual achievements on hunger and poverty. Such concerns are reflected in numerous debates within political, development, academic, and public spaces, and identify two major challenges to food production. One is the steady decline in cropping areas over the last decade, particularly paddy fields converted to other use. The other, still imprecise but even more worrisome, is that of climate change (see notably MARD 2008; Government of Viet Nam 2009). Both are valid concerns. While the problem of land conversion is discussed more at length in this issue by Tran Thi Thu Trang, the focus of this article is on the viability of the Vietnamese model of industrial agriculture, and the unlikelihood of it being able to sustain current levels of outputs, and with it food security, in the emerging context of the climate crisis.

The Intergovernmental Panel on Climate Change (IPCC) lists Viet Nam among those countries to be most affected by climate change (IPCC 2007; see also Dasgupta et al. 2009; ISPONRE 2009). Such vulnerability results from the combination of three factors: high exposure to natural elements, high sensitivity of socioeconomic structures to those elements, and low capacity to adapt by protecting structures or making them less sensitive (see notably Vogel and O'Brien 2004; Adger 2006; Eakin and Luers 2006; Füssel 2007; Nelson, Adger, and Brown 2007). Viet Nam's long coastlines, vast deltas, and location on the path of typhoons and monsoon rains mean that many parts of the country are widely exposed to weather extremes and sealevel rise (SLR) (Ninh, Trung, and Niem 2007, 2-3; Thuc 2009; CarewReid 2008, 7; Chaudhry and Ruysschaert 2007, 3-6; ICEM 2009). The unpredictability of climate extremes will affect not only coastal areas but also the entire country through changes in temperatures and rainfalls, likely resulting in more droughts, floods, flash floods, 


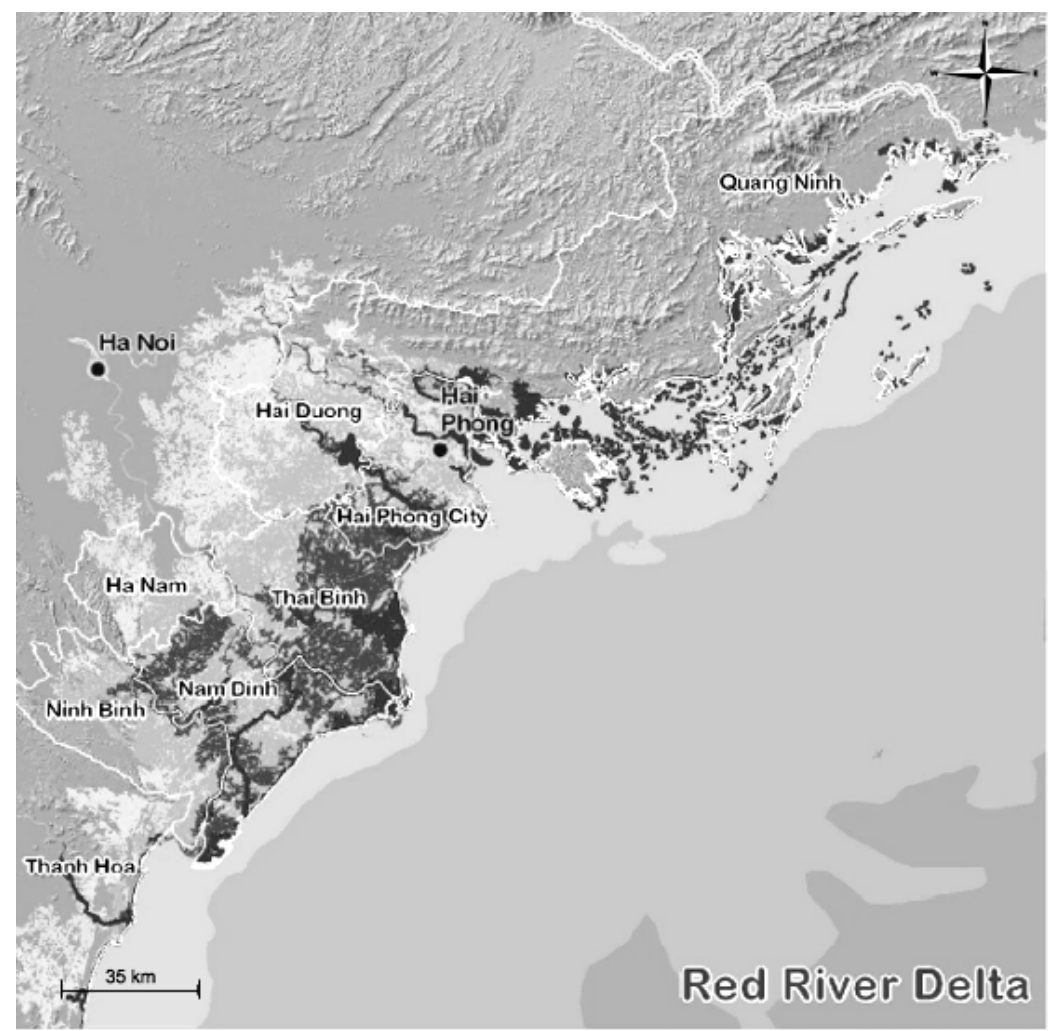

Inundated areas at SLR

\begin{tabular}{|l|l|l|l|l|}
\hline & & & & \\
\hline \hline 1 meter & 2 meters & 3 meters & 4 meters & 5 meters \\
\hline
\end{tabular}

Figure 1. Red River Delta.

Source: Carew-Reid 2008, 18; reproduced with permission from ICEM, Hanoi, 2011. Compass and scale added.

landslides, and the spread of pests as well as plant, animal, and human pathogenic vectors. In turn, sea-level rise will lead to flooding and saline water intrusion, notably within aquifers. Climate change scenarios, even among the optimistic ones, expect severe SLR impacts for the Red River and Mekong Deltas. At a mid-range (B2) IPCC scenario, now optimistic by most accounts, a one-meter SLR is expected by or before the end of the twenty-first century. At such a level, 4 percent of the Red 


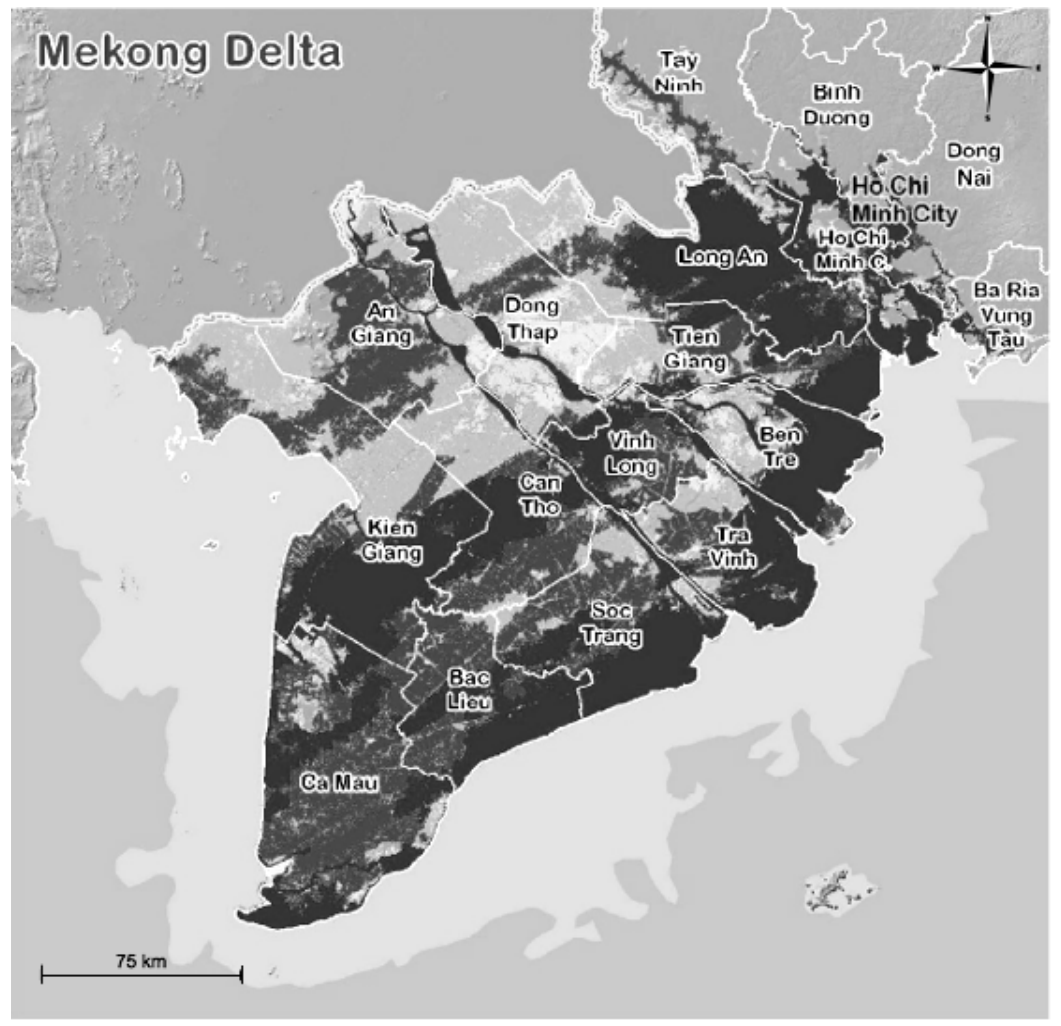

Inundated areas at SLR

\begin{tabular}{|l|l|l|l|l|}
\hline & & & & \\
\hline 1 meter & 2 meters & 3 meters & 4 meters & 5 meters \\
\hline
\end{tabular}

Figure 2. Mekong Delta.

Source: Carew-Reid 2008, 18; reproduced with permission from ICEM, Hanoi, 2011. Com pass and scale added.

River Delta would be submerged under seawater. For the Mekong Delta, however, it could be as much as 31 percent (Carew-Reid 2008, 14-15), as shown in figures 1 and 2.

These new environmental attributes will severely affect key livelihoods in agriculture, forestry, fisheries, and aquaculture, as well as public health and infrastructure (MONRE 2008; Granich, Kelly, and Nguyen Huu Ninh 1993; Chaudhry and Ruysschaert 2007, 5-6; 
ADPC 2003, 19-21). For this reason, Viet Nam is also vulnerable because of the high sensitivity of its socioeconomic structure to the above biophysical impacts. The country's economy, and agriculture in particular, is very much dependent on climate, with about three quarters of the population living either in low-lying fertile plains potentially affected by SLR and fluvial floods such as the Red River and Mekong deltas, or in mountainous areas exposed to flash floods and droughts (Ninh, Trung, and Niem 2007, 3; Carew-Reid 2008, 6).

Mechanisms of climatic impact on agriculture are by now well documented, with numerous global models of changing patterns providing ranges of expected outcomes. Globally, those outcomes will depend on several factors: (a) international greenhouse gases mitigation policies that are or not implemented, (b) evolving humidity and temperature patterns, (c) the pace of sea-level rise with associated land losses and salinization, (d) changes in the prevalence and geography of plant and animal pests, and (e) the actual carbon dioxide fertilization that will stimulate or not the growth of certain crops. Even in the bestcase scenarios, however, these factors are likely to affect very negatively the production, access to and utilization of food. There will be a net loss of suitable land for agriculture at tropical latitudes for any rate of temperature increase, destabilization of supplies by extreme weather events, and possible market restrictions in view of increased risks (such as limiting exports to maintain strategic reserves). The nutritional value and safety of food is also likely to be affected by unfavorable growing conditions, warmer weather, and water cleanness (Turral, Burke, and Faurès 2011; Batchelor et al. 2009; Bates et al. 2008; FAO 2008; Ericksen 2008; Ericksen et al. 2011; Schmidhuber and Tubiello 2007; and specifically for the case of Viet Nam see Yu et al. 2010; Nguyen Van Viet 2011). As a combined result of such threats, and simulating different variables, models applied to major grains (rice, wheat, maize, millet, sorghum) predict single and sometimes double-digit drop in production, and a 10-100 percent surge in food prices relative to nonclimate change scenario by 2050 (Nelson et al. 2009, 5-9; see also Cline 2007; Schmidhuber and Tubiello 2007, 19706; Rosegrant et al. 2008, 19; McIntyre et al. 2009, 47-49; Battisti and Naylor 2009; Nellemann et al. 2009; Fedoroff et al. 2010, 833). Of particular relevance to Viet Nam, scenarios reviewed in Nelson, Rosegrant et al. $(2009,4-5)$ indicate how irrigated rice will likely be severely affected by climate change, loosing up to 19 percent in crop productivity, even 
before accounting for land-use change, salinization, or other abiotic stresses.

The third factor of Viet Nam's vulnerability is its adaptive capacitythat is, the ability "to better cope with, manage or adjust to some changing condition, stress, hazard, risk or opportunity" (Smit and Wandel 2006, 282). This capacity is constrained by the country's limited financial resources, reflected in a purchasing power parity of just under USD 3,000 per capita (IMF 2010). In addition, poorer people within the country, especially poor women and youth, are often the most exposed and sensitive to climate change, involved for example in agricultural livelihoods on disaster-prone lands. Those groups are also the less endowed and empowered to recover from disruptions and for shifting to alternative livelihoods (Adger 1998, 5, 10-11; OXFAM International 2008, 13; Chaudhry and Ruysschaert 2007, 2). It could be argued, in turn, that the Vietnamese society has a long history of adaptation to structural change, notably foreign occupations, wars, and natural disasters (Kelly and Adger 2000; Adger 1999, 2000), which should bode well for its ability to face emerging climatic threats. Yet, as will be discussed below, the economic reforms that have redefined the country's productive and social relations since the 1980s may also have inadvertently but severely weakened that adaptive capacity.

Viet Nam is therefore vulnerable to climate change for being exposed to natural elements, for being a society and an economy sensitive to that exposure, and for having limited means and decreasing options to adapt by mitigating impacts or reducing sensitivity. Beyond land conversion and climate change, however, it is also worth mentioning that the country's agriculture is facing other but largely ignored structural constraints, which could have significant synergetic impacts (see discussion on multiple stressors in O'Brien and Leichenko 2000; O'Brien et al. 2004; Eakin and Luers 2006; Adger and Barnett 2009; McIntyre et al. 2009, 50; Max-Neef 2010). First, industrial agriculture depends on the continuous availability of fossil fuels for both energy and agrochemical inputs, requiring "ten calories of fuel for every calorie of food produced-and this does not include the energy used in processing, packaging, and shipping the final product to market" (Philipps 2007, 97; see also Vandermeer et al. 2009; Martínez Alier 2011). Yet, like the rest of the world, Viet Nam is already facing the end of cheap fossil fuels, with production peaking and average prices rising for both energy and agrochemical inputs (Viet Nam Business 
News 2010). In addition to this global fossil fuel crisis, Viet Nam is also under further energy constraints from problematic hydroelectric production due to repeated droughts over the last decade (Binh et al. 2010). As electrical power is supplied to priority urban and industrial areas, interruptions in the past few years have been particularly severe for the countryside. This has impacted most industrial agriculture, in which electrical power is extensively used, notably for irrigation and processing (Vietnam Peasant Association 2010).

Second, Viet Nam's industrial agriculture also depends on a stable global trade regime for the country's realization of a large share of its high-value production. It currently imports more than one-third of its agrochemical inputs and raw materials to produce further inputs domestically, while three quarters of hybrid rice seeds are procured from China (GRAIN 2008). Viet Nam also depends on global trade to commodify its production: it has exported nearly 80 percent of its GDP in 2008 (GSO 2009a), while the KOF Index of Globalizationmeasuring economic, social, and political indicators of global integration-nearly doubled since the start of doi moi, raising from 25 in 1987 to 48 in 2007 (KOF 2007). This exposure to global markets is already reflected in fluctuations of commodity prices and sporadic contractions of foreign markets (Greenfield 2004; Trang 2009). As the neoliberal global trade regime shows signs of fatigue, the jury is out on whether or not this may lead to the shrinking of that paradigm in the coming years (see notably Panitch and Gindin 2009, 21-29; Radice 2009; Chorev and Babb 2009; Gills 2010), but points toward a possible wave of re-regulation which would constrain global markets, and foreclose the opportunities that Viet Nam's modern agriculture has invested in.

\section{DOMINANT RESPONSE}

While little is said of the energy and trade stressors, the Vietnamese state has fully acknowledged and has been very concerned about how climate change may systematically disrupt its economy, and its agriculture and food security in particular. For many years now, government agencies have responded to the threat by building research and institutional capacity, and by devising policies in priority sectors. In 2008, the Ministry of Agriculture and Rural Development (MARD) adopted an Action Plan Framework for Adaptation to Climate Change in the Agriculture and Rural Development Sector for 2008- 
2020. The document raised numerous red flags with respect to agricultural production, food security, and natural disasters. In December 2008, the prime minister adopted the National Target Programme in Response to Climate Change (NTP-RCC) prepared by the Ministry of Natural Resources and Environment (MONRE). The NTP-RCC explicitly raises food security risks with particular attention to rice and fisheries (Government of Viet Nam 2008). By late 2009, the prime minister issued a resolution on national food security, questioning land conversion and calling for renewed efforts to increase agricultural productivity through expanded irrigation, other hydraulic engineering works, and agricultural research (Government of Viet Nam 2009). In practice, the government's response has indeed planned for better flood protection infrastructure, including a 2008 MARD proposal for USD 676 million investment in dike enhancement across the country (Biggs et al. 2009, 212), as well as modified crop cycles and technological solutions such as hybridization and genetic modification for increased tolerance to heat, drought, water logging, pest, or salinity (MONRE 2003, 66). Most recently, the Institute of Hydro-meteorological and Environmental Sciences has also revised upward its assessment of biophysical impacts, beyond the IPCC's midrange B2 scenario. The authority expressed particular concerns with respect to agricultural livelihoods and production in the Mekong Delta (Viet Nam News 2011).

\section{Assumptions about Mitigation}

The strategic paradigm reflected by those policy documents is well in line with Viet Nam's own continuum of modernist aspirations, and also echoes the discourse and practice that drives global capitalism to its green economy redux through ecological modernization (Fortier 2010; and theoretical discussion in Foster 2008, 536-40; Bäckstrand and Lövbrand 2007, 126-31; Luke 1996, 6-13; Brooks, Grist, and Brown 2009). It resonates with policies advocated by international development agencies and the agrifood industry that emphasize environmental control, biotech research, and technological intensification toward a climate-smart agriculture, and promote climateready policies based on better information gathering and sharing (see, for example, ADPC 2003, 25-27; UNFCCC 2006; Nelson, Rosegrant et al. 2009; Fedoroff et al. 2010; World Bank 2010, 154-56; UK Government Office for Science 2011; and specifically for Viet Nam, Yu et al. 2010). 
However, there is scant evidence that institutional development and technological innovations could in fact deliver the pace and type of fixes that would sustain current economic activities, including industrial agriculture. On the one hand, global GHG mitigation efforts are failing to provide any hope of climate stabilization, which Viet Nam would need as any other country to maintain its growth trajectory. Despite the accepted target of $2^{\circ} \mathrm{C}$ increase in global average temperature above preindustrial levels (Smith et al. 2009; Richardson 2009), current voluntary abatement pledges from the Cancún Agreements are well off the mark, and not much more is expected from Durban. Even if those pledges were implemented by 2020, followed by long-term draconian reductions, it would still leave emission gaps of 3-16 $\mathrm{GtCO}_{2} \mathrm{e}$ per year-that is, 7-36 percent too high (UNEP 2011). Such emission pathways are well above what would give a minimum chance of keeping the global average temperature within the $2^{\circ} \mathrm{C}$ target (Anderson and Bows 2008; Rogelj et al. 2011). Furthermore, that 2 ${ }^{\circ} \mathrm{C}$ threshold has itself long been contested for being overly optimistic about Earth system stability (Hansen 2005, 277). In recent years, several key articles were published focusing on $\mathrm{CO}_{2}$ concentration targets, highlighting how current levels (391 ppm $\mathrm{CO}_{2}{ }^{1}$, and rising about 2 ppm per year) already have deleterious impacts on measurable long-term climatic trends. Conclusions are that safer targets for climatic stability should be at $350 \mathrm{ppm} \mathrm{CO}_{2}$, possibly even $300 \mathrm{ppm}$, for a maximum rise in temperature of $1.5^{\circ} \mathrm{C}$ (Hansen 2005, 275; Hansen et al. 2008, 226; Rockström et al. 2009a, 2009b). The magnitude of greenhouse gases abatement required to stay within the not-so-safe limit of $2{ }^{\circ} \mathrm{C}$, let alone $1.5^{\circ} \mathrm{C}$, and the time frame within which these are needed, would therefore require tremendous regulatory incentives and institutional support. Yet as seen above, the mitigation strategy of ecological modernization and its green economy falls well short of such an effort. The global governance model of the industrial society, despite two decades of explicitly confronting climate change, remains unable to face the cumulative stress that will eventually lead to dysfunctional production, including that of its agricultural model. While Viet Nam alone, through its relatively small contribution to past or even present GHG emissions, cannot take much blame for such trends, its current response does nothing either to prevent further environmental damage or foster realistic mitigative actions.

On the other hand, ecological modernization rests its hopes on the rapid development and deployment of sociotechnical systems 
(technologies with institutions, knowledge, and relations of power), which assumes that capacity will be forthcoming to (a) drastically reduce GHGemissions through much lower material-energy throughput, measured as the carbon intensity of wealth created (Pacala and Socolow 2004), and (b) reabsorb GHG in excess of "overshooting" thresholds before points of no return are passed in climatic disequilibrium, notably through land-use management (Bäckstrand and Lövbrand 2006). It then becomes essential to assess whether the proposed technological response can indeed reasonably be expected to quickly and thoroughly decarbonize economic activities, provide significant GHG sequestration, or eventually geo-engineer the climate if the pace and scope of those other outcomes fall short.

On close examination, however, those assumptions are unsubstantiated for a number of reasons. Like mitigation targets, they too are unrealistic, turning the hopes of the green economy into a misguiding mirage. For one, the actual carbon intensity reduction of the past two decades has been of 0.7 percent per year. Yet, even if global emissions were to peak in 2015, and accounting for population and economic growth, the world economy would need to reduce that carbon intensity by 7 percent a year-that is, ten times faster than it actually is-to have a reasonable chance of not raising average temperature by more than $2{ }^{\circ} \mathrm{C}$ (Jackson 2009). Furthermore, emission reductions expected from energy efficiency policies and carbon capture and storage systems are likely overestimated, mostly due to the energy penalty of some of those technologies, their scaling-up, non- $\mathrm{CO}_{2}$ pollution, rebound effect on actual demand, transition costs, and vested interests (Arvesen, Bright, and Hertwich 2011; Sathre et al. 2011; see also Jacobson 2009). As Jackson $(2009,83)$ points out, technological breakthroughs in energy generation, sequestration, or geo-engineering are not impossible, and could very well come from nanotechnology and synthetic biology (see also ETC Group 2004; Kunstler 2005; Hällström 2008). But they would need to overcome inherent risks and trade-offs of innovations, and kick in fast and large to generate the magnitude of decoupling needed between economic growth and the material-energy throughput. Yet no such technologies are more than unproven concepts, several years, and sometimes decades, away from testing, let alone safe commercialization. Furthermore, this says nothing of the political economy of their eventual deployment, notably the distribution of their benefits, costs, and risks (Moe 2010). Therefore, to suggest that, and act as if, sociotechnological innovations will 
necessarily or even likely provide safe levels of decarbonization and sequestration, is dangerously delusive.

\section{Assumptions about Adaptation}

The above argument suggests that the ongoing failure of institutional reforms for adequate global environmental governance, and the unrealistic reliance on technological innovation, make it virtually impossible to avoid a gradual and possibly rapid decline of industrial agriculture outputs over the next few decades. This is true globally, and particularly for countries like Viet Nam that are highly vulnerable to climate change. Beyond such mythical decarbonization, the green economy discourse also rests on promises of robust adaptation, enabling to face whatever changes end up occurring. In the sphere of food production, this translates into climate-smart agriculture and a second wave of the Green Revolution.

Yet, the scope and depth of such adaptive measures is also unrealistic, while in fact industrial agriculture is proving to be inherently and ever more incapable of facing the challenges of multiple stressors, particularly that of climate change. First, the model constantly weakens its ecological foundation, as productivity is contingent upon continued and intensifying "biophysical override" (Weis 2010). It increases pressure on resources-notably water, land, and energy-and accelerates soil impoverishment, the inadvertent breeding of superweeds, the degradation of ecological services, and the spread of eco- and humantoxics. Those incompatibilities between industrial agriculture and the environment expose the former's abuses and systemic destabilization of the latter, and its increased fragility under environmental change (Blaikie and Brookfield 1987; Keil et al. 1998; Lipietz 2000; Adger et al. 2001; Bello 2004; Peet and Watts 2004; Bäckstrand and Lövbrand 2007, 131-36; Forsyth 2003; Friedmann and McNair 2008; Vandermeer et al. 2009; McMichael 2009a; Moore 2010; Weis 2007, 2010; Foley et al. 2011). Ultimately, as Vietnamese ecosystems are disrupted, the natural resource base of livelihoods is necessarily weakened (Taylor 2007, 11-12).

Second, the industrialization of agriculture has made farmers increasingly dependent on complex production and circulation processes, both within and outside agriculture. For example, up to a few decades ago, peasants of the Mekong Delta used to live with floods rather than control them, profiting from alluvial fertilization. They grew varieties of rice that took longer to mature but better adapted to 
seasonal hydraulic variations (see notably Sneddon and Binh 2001; Be, Sinh, and Miller 2007, 37-39). High dikes built across the Mekong Delta have reduced natural soil fertility for lack of sediments, leading to the increased use of agrochemicals, higher production costs, and increased water pollution. The opportunity for extra income and proteins that many poor households drew from fishing across flooded fields is also gone (Käkönen 2009, 208). The extent and magnitude of such landscape engineering required by industrial agriculture for irrigation, drainage, and salinity protection has in turn increased systemic sensitivity to environmental risks (for similar argument beyond Viet Nam, see Brooks, Grist, and Brown 2009, 751). Hydraulic systems are conceived within predictable ranges of variability, notably of water flow across river basins and weather patterns. Yet, such variability is increasingly unpredictable and reaches ever greater extremes, both as a result of resource overuse and of climate change. During the last decade, rainfall patterns have already changed in Viet Nam, with fewer precipitations in the north and more in the south (ISPONRE 2009, xv). In addition, several new dams are being commissioned upstream on the Mekong-most significantly in China but also in Laos, Cambodia, and Thailand-which will affect the river's flow in yet uncertain ways but are likely to compete for depleting freshwater resources, and accelerate erosion, siltation, and salinization across the delta and within its aquifers (Vaidyanathan 2011).

Similarly, the process of modernization has prioritized accumulation through productivity at the expense of rural livelihoods and environmental sustainability, leading to the reclamation of much flood plains, wetlands, and shallow coastlines (see notably Adger 1999, 253; Lebel et al. 2009, 283), and increasing demand for both water control and use (Miller 2007, 199). The overexploitation of underground water for household use and economic activities has reached alarming levels, with research expecting the exhaustion of some Mekong Delta aquifers by 2013 if no urgent measures are taken (Nuber and Stolpe 2008; VOV News 2009). As sea level rises, the depletion of underground water and drainage of traditional flood plains makes flooding and saline penetration ever more frequent and consequential. All these factors will combine to make the country's extensive irrigation system less effective, and commensurately affect agricultural productivity (Sneddon and Nguyen Thanh Binh 2001; Le S. Long 2007; VietNamNet Bridge 2009; Käkönen 2009; Biggs et al. 2009, 211-12; VietNamNet Bridge 2010). This is particularly worrisome 
considering that the Mekong Delta produces half of the country's rice and most of its surpluses and exports, but will also be one of the most severely affected region by freshwater shortages and sea-level rise. In a context of systemic dependency, the model of industrial agriculture is therefore exposing Viet Nam to a new vulnerability, weakening its resilience to external shocks, which could indeed void the successes achieved in food security over the last three decades.

Third, and maybe most importantly in the long term, industrial agriculture has affected the adaptability of Vietnamese farmers. The technologies of the Green Revolution have led to monocultures of high-yielding varieties. Across Viet Nam's ecological zones, few modern and hybrid cultivars have replaced a large number of traditional ones that were well suited to their local climatic and biotic attributes, be it rain patterns, salinity, acidity, temperature, or pest prevalence. By constraining access to natural resources, reducing genetic diversity, knowledge, skills, and social networks, and now enclosing species within intellectual property fences, industrial agriculture has created technological and institutional path dependencies. This is foreclosing alternative options, some of which are becoming more than ever necessary for adapting to quickly evolving hydraulic and climatic conditions and to make the food production system more resilient (Adger 1999, 252-57; Perkins 2003; Young et al. 2006, 313; Taylor 2007, 11-12; FAO 2008, 44-45; Altieri and Koohafkan 2008; ETC Group 2009, 8-14; Brooks, Grist, and Brown 2009, 745-61; Havaligi 2009; Moore 2010, 399).

While aligned on the global discourse of ecological modernization, the Vietnamese response to the climate crisis therefore rests on unsubstantiated technological and institutional assumptions. On the one hand, the measures so far internationally agreed to mitigate GHG emissions fall well short of the magnitude and timing that the latest science indicates would have some chance of preserving climatic equilibrium. Furthermore, the potential of the technological solutions proposed to deliver such insufficient abatement, or to adapt to changes that cannot be avoided, is either overestimated or yet unproven, for want of research and operational deployment. On the other hand, Viet Nam's adaptation strategy is based on, and builds its expectations from, a paradigm threatened not only by multiple structural stressors but also by internal dynamics that render the model ever more precarious at three levels: it has weakened the ecological foundation of agriculture through biophysical override; it has increased dependence on 
complex production and circulation processes both within and outside agriculture; and it has locked the development of that agricultural model into path dependencies through technical, knowledge, and institutional homogenization that is now foreclosing alternatives, reducing options for resilience and adaptation.

\section{Circular Metabolism}

The underlying logic of industrial production and consumption, including modern agriculture in Viet Nam as discussed above, is essentially linear: an ever increasing amount of energy and material resources are mobilized at one end, creating both wealth and waste at the other (Murota 1998; Jones, Pimbert, and Jiggins 2011). Since the Earth is a finite system, except for a constant input of solar energy, the use of resources and the sinking of waste are bound to hit limits. This is now happening on numerous and widening fronts, including energy and freshwater scarcity, biodiversity losses, and climate change (Rockström et al. 2009a). To maintain functionality in a finite system, processes have to be circular, with all outputs being recycled into new inputs, with new energy (solar in the Earth's case) compensating for entropic loss. The argument of the previous sections underlines how much a new model is urgently needed, in Viet Nam as elsewhere, to address the inherent contradictions of industrial agriculture and emerging structural stressors.

For the past five decades, the realization of such limits and the conception and experimentation on alternatives have sprung and matured (including notably Bookchin 1962; Carson 1962; GeorgescuRoegen 1971; Meadows, Club of Rome, and Potomac Associates 1974; Blaikie and Brookfield 1987; Keil et al. 1998; Peet and Watts 2004; Foster, Clark, and York 2010). With respect to agriculture, limits and alternatives have also long been debated in both the scientific and policy literature (Weis 2007; McIntyre et al. 2009; McMichael 2009a; UNCTAD 2010; de Schutter 2010; Vía Campesina 2010; Moore 2010; Weis 2010; Woodhouse 2010; Hoffmann 2011; Foley et al. 2011). It has become clear that only by steering away from industrial processes will agriculture drastically reduce, and eventually reverse, its GHG emissions, and prevent the crossing of other planetary boundaries (Funes 2002; Borron 2006; Nelson, Scott et al. 2009; GRAIN 2009; Jones, Pimbert, and Jiggins 2011). Also, and crucially, the most robust of such alternatives underline the interaction of both 
technological and social dimensions, showing how ecologically sustainable solutions cannot be socially viable without a new organization of production, distribution, and consumption. Such coupling of social and technological dimensions implies the transformation of current linear practices toward a paradigm of circular metabolism, along with the restructuring of social relations that value such ecosystemic continuity and resilience well above the current model of individual-centric short-term maximized utility. This new sociotechnical paradigm of agriculture is taking different forms and labels, including those of agroecology, permaculture, or ecological architecture, along with organizing principles of food sovereignty (see Trang in this issue, as well as Lee 2007; Pimbert 2008; Holt-Giménez 2009; Borras 2010). The common thread between those models is that in order to effectively address the multifaceted crisis of agriculture while feeding a growing global population of 7-9 billion, four synchronous pathways of reforms must be advanced:

1. Agroecological production. To enable the circular metabolic objective of eliminating agrochemical inputs and reduce energy use, these will need to be substituted with higher labor intensity; smaller production scales; cooperative and reciprocity arrangements; and the de-globalization, localization, and shortening of commodity chainstransformed into proximity trading webs. It will also require the rebuilding of resilient agrobiodiversity, as well as a rich and dispersed knowledge in agroecological metabolism (Rosset 2003; Weis 2007; Friedmann and McNair 2008; Ploeg 2008; Altieri 2009; Weis 2010; Reardon and Perez 2010).

2. Socialized production. Such a transformation of production processes will necessarily confront the political economic resistance of interests vested in the current industrial agriculture and food system, from upstream agrochemical suppliers and farmers locked in technological and commercial path dependencies, to downstream food processing industries, conglomerate retailers, and the array of financiers and marketeers all along that chain. To face this resistance to agroecology, and reclaim their long overdue control over production and accumulation, farmers will need to reappropriate their means of 
production, notably land, water, species, and knowledge, in a process that some have characterized as repeasantization (Ploeg 2007; Sevilla Guzman and Montiel 2009; Vanhaute 2011; see also Weis 2007; Borras 2008; Rosset 2009; McMichael 2009b; Rosset 2011; Torrez 2011).

3. Prioritized consumption. The linear character of industrial agriculture is at the root of its destructive impact, for its depletion of soils and biodiversity, its exhaustion of natural resources, and its environmental externalitiesincluding climate change. The magnitude of energy and material imbalances also stems from the nature of goods such a system delivers, driven by market profitability rather than actual needs. While agroecology offers alternatives to the procedural dead-ends of industrial agriculture (how goods are produced), food sovereignty also undertakes to change what is produced. This is a necessary step in reducing the energy-material throughput and its pressure on ecosystems, while ensuring the most efficient response to societal needs. Most notably, this requires ending the production of biofuels and reducing wastes from food processing and commodification, but also demands a shift from energy-, water-, and grainintensive commodities, such as meat and dairy products or all-season luxury fruits and vegetables, toward directly and locally consumable food of high nutritional quality and safety (ETC Group 2009; de Schutter 2009; Magdoff and Tokar 2009; McMichael 2009c; Stehfest et al. 2009; Foley et al. 2011).

4. Fair distribution. Close to a billion people are food insecure in the current system despite high levels of productivity and intensive resource use (FAO and WFP 2010; Foley et al. 2011). This systemic failure is bound to increase in a world of ever more depleted resources and saturated environmental sinks. As discussed earlier, the rhetorical response of industrial agriculture to that crisis is to further intensify outputs through a renewed Green Revolution. In turn, the food sovereignty perspective argues that current production is sufficient, and even excessive, if it focuses on direct consumption and is more equally distributed. It 
reasserts the social function of food beyond commodity production and profit accumulation, as livelihood and in fulfilling the universal right to food through selfconsumption and community solidarity. The food sovereignty perspective therefore establishes institutional redistribution mechanisms, such as in-kind grants to vulnerable groups, schools and hospitals, food-for-work, and affordable local markets (Schiavoni and Camacaro 2009; Wright 2009).

We have seen that the ecological modernization of the green economy rests on speculative technological and institutional assumptions. Those claimed solutions remain, however, to develop or to scale up, beyond what is realistic for the timing and magnitude needed. In contrast, agroecology and food sovereignty revert to long-proven agricultural practices, enhanced with newer but well-tested knowledge, and which provide sustainable use of resources, stronger biodiversity, and more resilience to environmental change, while delivering high levels of outputs (Altieri and Koohafkan 2008; Altieri 2009; McIntyre et al. 2009; de Schutter 2010; Vasilikiotis 2010; Vía Campesina 2010). This alternative model also rests on a sociopolitical organization of decentralized and democratized power over production, distribution, and access to food that has proven robust at times of crisis (for the example of Cuba, see Wright 2009; Reardon and Perez 2010; Machín Sosa et al. 2010; Rosset et al. 2011).

\section{CONCLUSION}

In Viet Nam over the past three decades, modernization has brought tremendous increases of food production and productivity, leading to significant surpluses and exports. There are, however, mounting threats, notably that of climate change, which could quickly void those gains and affect the country's food security. The response by Vietnamese authorities and most development actors has been to invest in further agricultural modernization, notably through expanded irrigation systems and the adoption of yet higher-yielding varieties and climateproofed species. This reflects the modernization approach that Viet Nam has adopted for half a century, and the globally prevalent ecological modernization discourse of green capitalism. It makes a politically convenient act of faith in technological and institutional 
innovations, both for reducing GHG emissions to mitigate the magnitude of climate change, and for building the resilience of an industrial agriculture that would supposedly keep increasing its productivity despite the challenging context. In fact, it is often argued that only industrial agriculture can possibly feed a growing world population (for example, Fedoroff et al. 2010).

Yet the presumption of techno-institutional salvation not only fails to recognize the inherent limits of modernized agriculture but also obfuscates the instability of the model in the context of climate change, and how precarious it renders food security. The overall picture of Viet Nam's agriculture is by now one deeply and increasingly embedded in complex and global commodity chains requiring energy-intensive production, mechanical and chemical processing, packaging, transportation, storage, and refrigeration. It requires efficient norms, rules, and institutions of international trade, and a sustainable environment that provides the needed ecological services. Yet, energy supplies, agrochemicals, engineered processes such as irrigation and drainage, trade stability and, in particular, environmental change, are all areas of intensifying crisis. In the context of systemic dependency as described in this article, industrial agriculture is now deceptively exposing Viet Nam to new sources of vulnerability, weakening its resilience to external shocks that could indeed blow away the deceivingly proud castle of cards it has built around agriculture and food security for the past thirty years.

Beyond the critique of that model, this article has argued that there is a compelling nexus between agroecology and food sovereignty that tackles the necessity of feeding a growing population with that of radically reducing agriculture's ecological footprint, while in fact rebuilding circular metabolic processes. That sociotechnical paradigm is in this sense a far superior model to industrial agriculture, and there is a quickly growing body of literature discussing the theory and ongoing experiences of moving from the latter to the former in the broader context of a transition beyond industrial capitalism (see notably Bello 2004; Cheynet 2008; Victor 2008; Latouche 2009; Kempf 2009, 115-34; Jackson 2009; Martínez Alier 2009). The next question is to see how such a paradigm can take hold in a country like Viet Nam, despite the creeping interests now deeply vested in agroindustrial accumulation. Supporting the still very few agroecology and food sovereignty initiatives, and engaging in related policy debates, will be compelling and urgent contributions to that shift. 


\section{Note}

1. National production in 1995 was 25 million tons, of which 12.8 million tons were from the Mekong Delta. Respective preliminary figures for 2008 were 38.7 million tons and 20.7 million tons. Hence: $(20.7-12.8) /(38.7-25)=57 \%(G S O 2009 b)$.

\section{REFERENCES}

Adger, W. Neil. 1998. "Indicators of Social and Economic Vulnerability to Climate Change in Vietnam.” CSERGE Working Paper GEC 98-02. Norwich: The Centre for Social and Economic Research on the Global Environment (CSERGE).

—. 1999. "Social Vulnerability to Climate Change and Extremes in Coastal Vietnam." World Development 27 (2): 249-69.

—. 2000. "Social and Ecological Resilience: Are They Related?" Progress in Human Geography 24 (3): 347-64.

- 2006. Vulnerability. Global Environmental Change 16 (3): 268-81.

Adger, W. Neil, and Jon Barnett. 2009. "Four Reasons for Concern about Adaptation to Climate Change." Environment and Planning A 41 (12): 2800-805.

Adger, W. Neil, Tor A. Benjaminsen, Katrina Brown, and Hanne Svarstad. 2001. "Advancing a Political Ecology of Global Environmental Discourses." Development E⿱ Change 32 (4): 681-715.

ADPC (Asian Disaster Preparedness Center). 2003. Climate Change and Development in Vietnam: Agriculture and Adaptation for the Mekong Delta Region. ADPC and Deutsche Gesellschaft für Technische Zusammenarbeit (GTZ) GmbH.

Altieri, Miguel A. 2009. "Agroecology, Small Farms, and Food Sovereignty." Monthly Review: An Independent Socialist Magazine 61 (3): 102-13.

Altieri, Miguel A., and Parviz Koohafkan. 2008. Enduring Farms: Climate Change, Smallholders and Traditional Farming Communities. Vol. 6. Penang: Third World Network (TWN).

Anderson, Kevin, and Alice Bows. 2008. "Reframing the Climate Change Challenge in Light of Post-2000 Emission Trends." Philosophical Transactions of the Royal Society A: Mathematical, Physical and Engineering Sciences 366 (1882): 3863-82.

Arvesen, Anders, Ryan M. Bright, and Edgar G. Hertwich. 2011. "Considering Only First-Order Effects? How Simplifications Lead to Unrealistic Technology Optimism in Climate Change Mitigation. Energy Policy 39 (11): 7448-54.

Bäckstrand, Karin, and Eva Lövbrand. 2006. "Planting Trees to Mitigate Climate Change: Contested Discourses of Ecological Modernization, Green Governmentality and Civic Environmentalism." Global Environmental Politics 6 (1): 50-75.

—. 2007. "Climate Governance beyond 2012: Competing Discourses of Green Governmentality, Ecological Modernization and Civic Environmentalism.” In The Social Construction of Climate Change: Power, Knowledge, Norms, Discourses, edited by Mary E. Pettenger. Aldershot, Hampshire, England; Burlington, VT: Ashgate.

Batchelor, Charles, Ton Schouten, Stef Smits, Patrick Moriarty, and John Butterworth. 2009. "Climate Change and WASH Services Delivery: Is improved WASH Governance the Key to Effective Mitigation and Adaptation?" In Perspective Paper, Prepared for the 5th World Water Forum. The Hague: IRC International Water and Sanitation Centre. 
Bates, Bryson, Zbigniew W. Kundzewicz, Shaohong Wu, and Jean Palutikof. 2008. "Climate Change and Water." Intergovernmental Panel on Climate Change (IPCC) Technical Paper 6.

Battisti, David S., and Rosamond L. Naylor. 2009. "Historical Warnings of Future Food Insecurity with Unprecedented Seasonal Heat." Science 323 (5911): 240-44.

Bello, Walden. 2004. Deglobalization: Ideas for a New World Economy. New updated ed. London: Zed Books.

Bhaduri, Amit, and Muhammad Anisur Rahman, eds. 1982. Studies in Rural Participation. New Delhi: Oxford \& IBH.

Binh, D., V. Lam, N. Nam, and D. Nam. 2010. "Thieu nuoc, dien phap phu” [Water Shortage, Unstable Supply of Electricity]. Tuoi Tre Online, September 10.

Biggs, David, Fiona Miller, Chu Thai Hoang, and François Molle. 2009. "The Delta Machine: Water Management in the Vietnamese Mekong Delta in Historical and Contemporary Perspectives." In Contested Waterscapes in the Mekong Region: Hydropower, Livelihoods and Governance, edited by François Molle, Tira Foran, and Mira Käkönen. London; Sterling, VA: Earthscan.

Blaikie, Piers M., and Harold C. Brookfield, eds. 1987. Land Degradation and Society. London; New York: Methuen.

Bookchin, Murray. 1962. Our Synthetic Environment. 1st ed. New York: Knopf.

Borras, Saturnino M. 2008. "La Vía Campesina and Its Global Campaign for Agrarian Reform." Journal of Agrarian Change 8 (2-3): 258-89.

- 2010. "The Politics of Transnational Agrarian Movements." Development and Change 41 (5): 771-803.

Borron, Sarah. 2006. Building Resilience for an Unpredictable Future: How Organic Agriculture Can Help Farmers Adapt to Climate Change. Food and Agriculture Organization of the United Nations (FAO).

Brooks, Nick, Natasha Grist, and Katrina Brown. 2009. "Development Futures in the Context of Climate Change: Challenging the Present and Learning from the Past." Development Policy Review 27 (6): 741-65.

Carew-Reid, Jeremy. 2008. Rapid Assessment of the Extent and Impact of Sea Level Rise in Viet Nam. International Centre for Environmental Management (ICEM).

Carson, Rachel. 1962. Silent Spring. Boston: Houghton Mifflin.

Chaudhry, Peter, and Greet Ruysschaert. 2007. "Climate Change and Human Development in Viet Nam.” United Nations Development Programme (UNDP) Human Development Report Office Occasional Paper 2007/42.

Cheynet, Vincent. 2008. Le choc de la décroissance, Histoire immédiate. Paris: Éditions du Seuil.

Chorev, Nitsan, and Sarah Babb. 2009. "The Crisis of Neoliberalism and the Future of International Institutions: A Comparison of the IMF and the WTO." Theory and Society 38 (5): 459-84.

Cline, William R. 2007. Global Warming and Agriculture: Impact Estimates by Country. Washington, DC: Center for Global Development.

Dasgupta, Susmita, Benoit Laplante, Craig Meisner, David Wheeler, and Jianping Yan. 2009. "The Impact of Sea Level Rise on Developing Countries: A Comparative Analysis." Climatic Change 93 (3): 379-88.

de Schutter, Olivier. 2009. "The Meatification of Diets and Global Food Security." UN Special Rapporteur on the Right to Food. 
2010. Report Submitted by the Special Rapporteur on the Right to Food, Olivier De Schutter. United Nations General Assembly.

Eakin, Hallie, and Amy Lynd Luers. 2006. "Assessing the Vulnerability of SocialEnvironmental Systems.” Annual Review of Environment and Resources 31 (1): 365-94.

Ericksen, Polly J. 2008. "What Is the Vulnerability of a Food System to Global Environmental Change?" Ecology and Society 13 (2).

Ericksen, Polly, Philip Thornton, An Notenbaert, Laura Cramer, Peter Jones, and Mario Herrero. 2011. Mapping Hotspots of Climate Change and Food Insecurity in the Global Tropics. CGIAR Research Program on Climate Change, Agriculture and Food Security (CCAFS).

ETC Group. 2004. Down on the Farm: The Impact of Nano-scale Technologies on Food and Agriculture. Ottawa, ON, Canada: ETC Group.

—. 2009. Who Will Feed Us? Questions for Food / Climate Crises Negotiators in Rome and Copenhagen. ETC Group.

FAO (Food and Agriculture Organization of the United Nations). 2008. Climate Change and Food Security: A Framework Document. Rome: FAO.

FAO (Food and Agriculture Organization of the United Nations) and WFP (World Food Programme). 2010. The State of Food Insecurity in the World: Addressing Food Insecurity in Protracted Crises. Rome: FAO and WFP.

Fedoroff, N. V., D. S. Battisti, R. N. Beachy, P. J. M. Cooper, D. A. Fischhoff, C. N. Hodges, V. C. Knauf, D. Lobell, B. J. Mazur, D. Molden, M. P. Reynolds, P. C. Ronald, M. W. Rosegrant, P. A. Sanchez, A. Vonshak, and J.K. Zhu. 2010. "Radically Rethinking Agriculture for the 21st Century." Science 327 (5967): 833 34.

Fforde, Adam, and Steve Sénèque. 1994. The Economy and the Countryside in Vietnam: The Relevance of Rural Development Policies. Canberra: Research School of Pacific and Asian Studies.

Foley, Jonathan A., Navin Ramankutty, Kate A. Brauman, Emily S. Cassidy, James S. Gerber, Matt Johnston, Nathaniel D. Mueller, Christine O/'Connell, Deepak K. Ray, Paul C. West, Christian Balzer, Elena M. Bennett, Stephen R. Carpenter, Jason Hill, Chad Monfreda, Stephen Polasky, Johan Rockstrom, John Sheehan, Stefan Siebert, David Tilman, and David P. M. Zaks. 2011. "Solutions for a Cultivated Planet." Nature 478 (7369): 337-42.

Forsyth, Tim. 2003. Critical Political Ecology: The Politics of Environmental Science. New York: Routledge.

Fortier, François. 2010. "Taking a Climate Chance: A Procedural Critique of Viet Nam's Climate Change Strategy.” Asia Pacific Viewpoint 51 (3).

Foster, Emma A. 2008. "Sustainable Development Policy in Britain: Shaping Conduct through Global Governmentality.” British Politics 3 (4): 535-55.

Foster, John Bellamy, Brett Clark, and Richard York. 2010. The Ecological Rift: Capitalism's War on the Earth. New York: Monthly Review Press.

Friedmann, Harriet, and Amber McNair. 2008. "Whose Rules Rule? Contested Projects to Certify 'Local Production for Distant Consumers'." Journal of Agrarian Change 8 (2-3): 408-34.

Funes, Fernando. 2002. Sustainable Agriculture and Resistance: Transforming Food Production in Cuba. Oakland, CA: Food First Books.

Füssel, Hans-Martin. 2007. "Vulnerability: A Generally Applicable Conceptual Framework for Climate Change Research.” Global Environmental Change 17 (2): 155-67. 
GRAIN (Genetic Resources Action International). 2008. Vietnam: The High Stakes of Hybrid Rice for Farmers. Barcelona: GRAIN.

- 2009. Climate Crisis Special Issue. Barcelona: GRAIN.

GSO (General Statistics Office of Viet Nam). 2009a. "Key Indicators on National Accounts." GSO.

—. 2009b. "Production of Paddy by Province." GSO.

Georgescu-Roegen, Nicholas. 1971. The Entropy Law and the Economic Process. Cambridge, Mass.: Harvard University Press.

Gills, Barry K. 2010. "Going South: Capitalist Crisis, Systemic Crisis, Civilisational Crisis.” Third World Quarterly 31 (2): 169-84.

Government of Viet Nam. 2008. Quyet dinh phê duyet chuõng trình muc tiêu quoc gia ung phó voi bien doi khi hau [Approval of the National Target Program in Response to Climate Change]. Edited by Thu Tuong Chính Phu (Prime Minister Office). Hanoi.

- 2009. Nghi quyet so 63/NQ-CP ngay 23 thang 12 nam 2009 cua chinh phu ve dam bao an ninh luong thuc quoc gia [Government Resolution No. 63/NQ-CP of 23 December 2009 on Ensuring National Food Security]. Hanoi.

Granich, Sarah, P. Mick Kelly, and Nguyen Huu Ninh. 1993. Global Warming and Vietnam. Stockholm Environment Institute et al.

Greenfield, Gerard. 2004. "Vietnam and the World Coffee Crisis: Local Coffee Riots in a Global Context." Accessed September 22, 2010. http:// www.probeinternational.org/coffee/vietnam-and-world-coffee-crisis-local-coffeeriots-global-context.

Ha Vinh. 1997. Nong nghiep Viet Nam trong buoc chuyen sang kinh te thi truong. Hanoi: Social Sciences Publishing House.

Hällström, Niclas. 2008. "What Next? Climate Change, Technology and Development." Development 51 (3): 375.

Hansen, James. 2005. "A Slippery Slope: How Much Global Warming Constitutes 'Dangerous Anthropogenic Interference'?" Climatic Change 68 (3): 269-79.

Hansen, James, Makiko Sato, Pushker Kharecha, David Beerling, Robert Berner, Valerie Masson-Delmotte, Mark Pagani, Maureen Raymo, Dana L. Royer, and James C. Zachos. 2008. "Target Atmospheric CO2: Where Should Humanity Aim?" The Open Atmospheric Science Journal 2:217-31.

Havaligi, Neeraja. 2009. "Role of Agrobiodiversity and Indigenous Knowledge Conservation in Food and Global Health Security in the Climate Change Scenario." In Climate 2009. Virtual Conference.

Hoffmann, Ulrich. 2011. Assuring Food Security in Developing Countries under the Challenges of Climate Change: Key Trade and Development Issues of a Fundamental Transformation of Agriculture. United Nations Conference on Trade and Development (UNCTAD) Discussion Paper 201.

Holt-Giménez, Eric. 2009. "From Food Crisis to Food Sovereignty." Monthly Review: An Independent Socialist Magazine 61 (3): 142-56.

ICEM (International Centre for Environmental Management). 2009. Ho Chi Minh City Adaptation to Climate Change. ICEM.

IMF (International Monetary Fund). 2010. World Economy Outlook Database.

IPCC (Intergovernmental Panel on Climate Change). 2007. Climate Change 2007: Impacts, Adaptation and Vulnerability: Contribution of Working Group II to the Fourth 
Assessment Report of the Intergovernmental Panel on Climate Change. Edited by the IPCC Working Group II. Cambridge, UK and New York: Cambridge University Press.

IRRI (International Rice Research Institute). 2007. "Important Rice Production System under Pressure." ScienceDaily, October 10.

—. 2009. "IRRI World Rice Statistics (WRS)." http://beta.irri.org/solutions/ index.php?option $=$ com_content\& task $=$ view\&id $=250$.

ISPONRE (Institute of Strategy and Policy on Natural Resources and Environment). 2009. Viet Nam Assessment Report on Climate Change. ISPONRE.

Jackson, Tim. 2009. Prosperity without Growth: Economics for a Finite Planet. 1st ed. London; Sterling, VA: Earthscan.

Jacobson, Mark Z. 2009. "Review of Solutions to Global Warming, Air Pollution, and Energy Security.” Energy and Environmental Science 2 (2): 148-73.

Jones, Andy, Michel Pimbert, and Janice Jiggins. 2011. Virtuous Circles: Values, Systems and Sustainability, Reclaiming Diversity and Citizenship. London: International Institute for Environment and Development.

Käkönen, Mira. 2009. "Mekong Delta at the Crossroads: More Control or Adaptation?" AMBIO: A Journal of the Human Environment 37 (3): 205-12.

Keil, Roger, David V.J. Bell, Peter Penz, and Leesa Fawcett, eds. 1998. Political Ecology: Global and Local. Innis Centenary Series. New York: Routledge.

Kelly, P. Mick, and W. Neil Adger. 2000. "Theory and Practice in Assessing Vulnerability to Climate Change and Facilitating Adaptation." Climatic Change 47 (4): 325-52.

Kempf, Hervé. 2009. Pour sauver la planète, sortez du capitalisme, L’histoire immédiate. Paris: Éditions du seuil.

Kerkvliet, Benedict J. Tria. 1995. "Village-State Relations in Vietnam: The Effect of Everyday Politics on Decollectivization." The Journal of Asian Studies 54 (2): 396-418. KOF. 2007. KOF Index of Globalisation. KOF Konjunkturforschungstelle.

Kolko, Gabriel. 1997. Vietnam: Anatomy of a Peace. London; New York: Routledge.

Kunstler, James Howard. 2005. The Long Emergency: Surviving the Converging Catastrophes of the Twenty-first Century. New York: Atlantic Monthly Press.

Latouche, Serge. 2009. Farewell to Growth. Cambridge: Polity.

Le, Long S. 2007. "Stink over Vietnamese Food Exports.” Asia Times Online, December 12.

Lebel, Louis, Bach Tan Sinh, Po Garden, Suong Seng, Le Anh Tuan, and Duong Van Truc. 2009. "The Promise of Flood Protection: Dikes and Dams, Drains and Diversions." In Contested Waterscapes in the Mekong Region: Hydropower, Livelihoods and Governance, edited by François Molle, Tira Foran, and Mira Käkönen. London; Sterling, VA: Earthscan.

Lee, Richard. 2007. Food Security and Food Sovereignty. Centre for Rural Economy, University of Newcastle Upon Tyne.

Lipietz, Alain. 2000. "Political Ecology and the Future of Marxism." Capitalism Nature Socialism 11 (1): 69-85.

Long, Ngo Vinh. 1984. "Agrarian Differentiation in the Southern Region of Vietnam.” Journal of Contemporary Asia 14 (3): 283-305.

—_. 1993. "Reform and Rural Development: Impact on Class, Sectoral, and Regional Inequalities." In Reinventing Vietnamese Socialism: Doi Moi in Comparative Perspective, edited by William S. Turley and Mark Selden. Boulder: Westview Press.

Luke, Timothy W. 1996. Generating Green Governmentality: A Cultural Critique of Environmental Studies as a Power/Knowledge Formation. Blacksburg, VA: Department 
of Political Science, Virginia Polytechnic Institute and State University Blacksburg, VA.

Machín Sosa, Braulio, Adilén María Roque Jaime, Dana Rocío Ávila Lozano, and Peter Michael Rosset. 2010. Revolución agroecologica: El movimiento de campesino a campesino de la ANAP en Cuba. La Vía Campesina.

Magdoff, Fred, and Brian Tokar. 2009. "Agriculture and Food in Crisis." Monthly Review: An Independent Socialist Magazine 61 (3): 1-16.

MARD (Ministry of Agriculture and Rural Development). 2008. Action Plan Framework for Adaptation to Climate Change in the Agriculture and Rural Development Sector Period 2008-2020. Hanoi: MARD.

Marquis, Jefferson P. 2000. "The Other Warriors: American Social Science and Nation Building in Vietnam.” Diplomatic History 24 (1): 79.

Martínez Alier, Joan. 2009. "Socially Sustainable Economic De-growth.” Development and Change 40 (6): 1099-119.

—. 2011. "The EROI of Agriculture and Its Use by the Via Campesina." Journal of Peasant Studies 38 (1): 145-60.

Max-Neef, Manfred. 2010. "The World on a Collision Course and the Need for a New Economy.” AMBIO: A Journal of the Human Environment 39 (3): 200-210.

McIntyre, Beverly D., Hans R. Herren, Judi Wakhungu, and Robert T. Watson, eds. 2009. Agriculture at a Crossroad: International Assessment of Agricultural Knowledge, Science and Technology for Development (IAASTD) - Global Report. Washington, DC: Island Press.

McMichael, Philip. 2009a. "A Food Regime Analysis of the 'World Food Crisis'." Agriculture and Human Values 26 (4): 281-95.

—_. 2009b. "A Food Regime Genealogy." Journal of Peasant Studies 36 (1): 139-69.

_- 2009c. "Banking on Agriculture: A Review of the World Development Report 2008." Journal of Agrarian Change 9 (2): 235-46.

Meadows, Donella H., Club of Rome, and Potomac Associates. 1974. The Limits to Growth: A Report for the Club of Rome's Project on the Predicament of Mankind. 2 nd ed. New York: Universe Books.

Miller, Fiona. 2007. "Seeing 'Water Blindness': Water Control in Agricultural Intensification and Environmental Change in Mekong Delta, Vietnam." In Environment, Development and Change in Rural Asia-Pacific: Between Local and Global, edited by J. Connell and E. Waddell. New York, NY: Routledge.

Moe, Espen. 2010. "Energy, Industry and Politics: Energy, Vested Interests, and Longterm Economic Growth and Development." Energy 35 (4): 1730-40.

MONRE (Ministry of Natural Resources and Environment of Viet Nam). 2003. Viet Nam Initial National Communication under the United Nations Framework Convention on Climate Change. Hanoi: MONRE.

- 2008. Viet Nam Assessment Report on Climate Change (VARCC). Hanoi: MONRE.

Moore, Jason W. 2010. "The End of the Road? Agricultural Revolutions in the Capitalist World-Ecology, 1450-2010." Journal of Agrarian Change 10 (3): 389-413.

Murota, Takeshi. 1998. "Material Cycle and Sustainable Economy." In Political Ecology: Global and Local, edited by Roger Keil, David V.J. Bell, Peter Penz, and Leesa Fawcett. London: Routledge.

Nellemann, Christian, Monika MacDevette, Tom Manders, Bas Eickhout, Birger Svihus, Anne Gerdien Prins, and Bjørn P. Kaltenborn, eds. 2009. The Environmental Food Crisis - The Environment's Role in Averting Future Food Crises. A UNEP Rapid 
Response Assessment. Arendal, Norway: United Nations Environment Programme (UNDP).

Nelson, Donald R., W. Neil Adger, and Katrina Brown. 2007. "Adaptation to Environmental Change: Contributions of a Resilience Framework." Annual Review of Environment and Resources 32 (1): 395-419.

Nelson, Erin, Steffanie Scott, Judie Cukier, and Ángel Galán. 2009. "Institutionalizing Agroecology: Successes and Challenges in Cuba." Agriculture and Human Values 26 (3): 233-43.

Nelson, Gerald C., Mark W. Rosegrant, Jawoo Koo, Richard Robertson, Timothy Sulser, Tingju Zhu, Claudia Ringler, Siwa Msangi, Amanda Palazzo, Miroslav Batka, Marilia Magalhaes, Rowena Valmonte-Santos, Mandy Ewing, and David Lee. 2009. Climate Change: Impact on Agriculture and Costs of Adaptation. International Food Policy Research Institute (IFPRI).

Ninh, Nguyen Huu, Vu Kien Trung, and Nguyen Xuan Niem. 2007. "Flooding in Mekong River Delta, Viet Nam.” United Nations Development Programme (UNDP) Occasional Papers 2007/53: 23.

Nuber, Thomas, and Harro Stolpe. 2008. "Challenges of the Groundwater Management in Can Tho City, Vietnam." In BGR-Symposium, Sanitation and Groundwater Protection. Hannover.

O’Brien, Karen L., and Robin M. Leichenko. 2000. "Double Exposure: Assessing the Impacts of Climate Change within the Context of Economic Globalization." Global Environmental Change 10 (3): 221-32.

O’Brien, Karen, Robin Leichenko, Ulka Kelkar, Henry Venema, Guro Aandahl, Heather Tompkins, Akram Javed, Suruchi Bhadwal, Stephan Barg, Lynn Nygaard, and Jennifer West. 2004. "Mapping Vulnerability to Multiple Stressors: Climate Change and Globalization in India." Global Environmental Change Part A 14 (4): 303-13.

OXFAM International. 2008. Viet Nam: Climate Change, Adaptation and Poor People. Oxfam International.

Pacala, Stephen, and Robert Socolow. 2004. "Stabilization Wedges: Solving the Climate Problem for the Next 50 Years with Current Technologies.” Science 305 (5686): 968-72.

Panitch, Leo, and Sam Gindin. 2009. "The Current Crisis: A Socialist Perspective." Studies in Political Economy 83:7-31.

Pearce, Kimber Charles. 2001. Rostow, Kennedy, and the Rhetoric of Foreign Aid, Rhetoric and Public Affairs Series. East Lansing: Michigan State University Press.

Peet, Richard, and Michael Watts. 2004. Liberation Ecologies: Environment, Development, Social Movements. 2nd ed. London; New York: Routledge.

Perkins, Richard. 2003. “Technological 'Lock-in'.” In Internet Encyclopaedia of Ecological Economics. International Society for Ecological Economics.

Philipps, Paul. 2007. "Peak Oil and the Future of Agriculture: Has Cuba Shown the Way?" In Energy Security and Climate Change: A Canadian Primer. Black Point, NS: Fernwood Pub.

Pimbert, Michel. 2008. Towards Food Sovereignty: Reclaiming Autonomous Food Systems. IIED

Pincus, Jonathan, and John Sender. 2008. "Quantifying Poverty in Viet Nam: Who Counts?" Journal of Vietnamese Studies 3 (1): 108-50. 
Pingali, Prabhu L., Tri Khiem Nguyen, Roberta V. Gerpacio, and Tong Xuan Vo. 1997. "Prospects for Sustaining Vietnam's Reacquired Rice Exporter Status. Food Policy 22 (4): 345-58.

Ploeg, Jan Douwe van der. 2007. "The Third Agrarian Crisis and the Re-emergence of Processes of Repeasantization." Rivista di Economia Agraria 62 (3): 325-32.

- 2008. The New Peasantries: Struggles for Autonomy and Sustainability in an Era of Empire and Globalization. London; Sterling, VA: Earthscan.

Radice, Hugo. 2009. "Neoliberalism in Crisis? Money and the state in Contemporary Capitalism." Spectrum: Journal of Global Studies 1 (2).

Reardon, Juan Alberto Simon, and Reinaldo Aleman Perez. 2010. "Agroecology and the Development of Indicators of Food Sovereignty in Cuban Food Systems." Journal of Sustainable Agriculture 34 (8): 907-22.

Richardson, Katherine. 2009. "Climate Change: Global Risks, Challenges and Decisions (Synthesis Report).” Paper read at Climate Change: Global Risks, Challenges and Decisions (Synthesis Report), Copenhagen, March 10-12.

Rockström, Johan, Will Steffen, Kevin Noone, Asa Persson, F. Stuart Chapin, Eric F. Lambin, Timothy M. Lenton, Marten Scheffer, Carl Folke, Hans Joachim Schellnhuber, Bjorn Nykvist, Cynthia A. de Wit, Terry Hughes, Sander van der Leeuw, Henning Rodhe, Sverker Sorlin, Peter K. Snyder, Robert Costanza, Uno Svedin, Malin Falkenmark, Louise Karlberg, Robert W. Corell, Victoria J. Fabry, James Hansen, Brian Walker, Diana Liverman, Katherine Richardson, Paul Crutzen, and Jonathan A. Foley. 2009a. "A Safe Operating Space for Humanity." Nature 461 (7263): 472-75.

_.2009b. "Planetary Boundaries: Exploring the Safe Operating Space for Humanity." Ecology and Society 14 (2).

Rogelj, Joeri, William Hare, Jason Lowe, Detlef P. van Vuuren, Keywan Riahi, Ben Matthews, Tatsuya Hanaoka, Kejun Jiang, and Malte Meinshausen. 2011. "Emission Pathways Consistent with a 2C Global Temperature Limit.” Nature Climate Change. Advance online publication.

Rosegrant, Mark W., Mandy Ewing, Gary Yohe, Ian Burton, Saleemul Huq, and Rowena Valmonte-Santos. 2008. Climate Change and Agriculture, Threats and Opportunities. Deutsche Gesellschaft für Technische Zusammenarbeit (GTZ) GmbH.

Rosset, Peter. 2003. "Food Sovereignty: Global Rallying Cry of Farmer Movements." Food First Backgrounder, Fall.

—. 2009. "Fixing our Global Food System." Monthly Review: An Independent Socialist Magazine 61 (3): 114-28.

Rosset, Peter Michael. 2011. "Food Sovereignty and Alternative Paradigms to Confront Land Grabbing and the Food and Climate Crises." Development 54 (1): 21-30.

Rosset, Peter Michael, Braulio Machín Sosa, Adilén María Roque Jaime, and Dana Rocío Ávila Lozano. 2011. "The Campesino-to-Campesino Agroecology Movement of ANAP in Cuba: Social Process Methodology in the Construction of Sustainable Peasant Agriculture and Food Sovereignty.” Journal of Peasant Studies 38 (1): 161-91.

Sathre, Roger, Mikhail Chester, Jennifer Cain, and Eric Masanet. 2011. "A Framework for Environmental Assessment of CO2 Capture and Storage Systems.” Energy 37: $540-48$.

Schiavoni, Christina, and William Camacaro. 2009. "The Venezuelan Effort to Build a New Food and Agriculture System." Monthly Review: An Independent Socialist Magazine 61 (3): 129-41. 
Schmidhuber, Josef, and Francesco N. Tubiello. 2007. "Global Food Security under Climate Change." Proceedings of the National Academy of Sciences 104 (50): 19703-8.

Sevilla Guzman, Eduardo, and Marta Soler Montiel. 2009. "Del desarrollo rural a la agroecologia. Hacia un cambio de pardigma" [From Rural Development to Agroecology: Toward a Change of Paradigm]. Documentación social 155:23-39.

Smit, Barry, and Johanna Wandel. 2006. "Adaptation, Adaptive Capacity and Vulnerability." Global Environmental Change 16 (3): 282-92.

Smith, Joel B., Stephen H. Schneider, Michael Oppenheimer, Gary W. Yohe, William Hare, Michael D. Mastrandrea, Anand Patwardhan, Ian Burton, Jan CorfeeMorlot, Chris H. D. Magadza, Hans-Martin Füssel, A. Barrie Pittock, Atiq Rahman, Avelino Suarez, and Jean-Pascal van Ypersele. 2009. "Assessing Dangerous Climate Change through an Update of the Intergovernmental Panel on Climate Change (IPCC) 'Reasons for Concern'.” Proceedings of the National Academy of Sciences 106 (11): 4133-37.

Sneddon, Chris, and Nguyen Thanh Binh. 2001. "Politics, Ecology and Water: The Mekong Delta and Development of the Lower Mekong Basin." In Living with Environmental Change: Social Vulnerability, Adaptation and Resilience in Vietnam, edited by W. Neil Adger, P. Mick Kelly, and Nguyen Huu Ninh. London: Routledge.

Stehfest, Elke, Lex Bouwman, Detlef van Vuuren, Michel den Elzen, Bas Eickhout, and Pavel Kabat. 2009. "Climate Benefits of Changing Diet." Climatic Change 95 (1): 83-102.

Taylor, Philip. 2007. "Poor Policies, Wealthy Peasants: Alternative Trajectories of Rural Development in Vietnam." Journal of Vietnamese Studies 2 (2): 3-56.

Torrez, Faustino. 2011. "La Via Campesina: Peasant-led Agrarian Reform and Food Sovereignty." Development 54 (1): 49-54.

Thuc, Tran. 2009. "Climate Change in Vietnam and Response." In 7th FIG (International Federation of Surveyors) Regional Conference: Spatial Data Serving People: Land Governance and the Environment - Building the Capacity. Hanoi, Vietnam: Vietnam Institute of Meteorology, Hydrology and Environment.

Trang, Tran Thi Thu. 2009. "State-Society Relations and the Diversity of Peasant Resistance in Viet Nam." In Agrarian Angst and Rural Resistance in Contemporary Southeast Asia, edited by Dominique Caouette and Sarah Turner. London; New York: Routledge.

—_. 2010. "Social Differentiation Revisited: A Study of Rural Changes and Peasant Strategies in Vietnam.” Asia Pacific Viewpoint 51 (1): 17-35.

Turral, Hugh, Jacob Burke, and Jean-Marc Faurès. 2011. "Climate Change, Water and Food Security." United Nations Food and Agriculture Organization FAO Water Reports 36.

UK Government Office for Science. 2011. Foresight - The Future of Food and Farming: Challenges and Choices for Global Sustainability. The Government Office for Science.

United Nations Conference on Trade and Development (UNCTAD). 2010. "Agriculture at the Crossroads: Guaranteeing Food Security in a Changing Global Climate.” UNCTAD Policy Briefs 18.

United Nations Environment Programme (UNEP). 2011. Bridging the Emissions Gap. United Nations Environment Programme.

United Nations Convention on Climate Change (UNFCCC). 2006. Technologies for Adaptation to Climate Change. UNFCCC. 
Vaidyanathan, Gayathri. 2011. "Dam Controversy: Remaking the Mekong." Nature 478 (7369): 305-7.

Vandermeer, John, Gerald Smith, Ivette Perfecto, and Eileen Quintero. 2009. "Effects of Industrial Agriculture on Global Warming and the Potential of Small-Scale Agroecological Techniques to Reverse Those Effects." La Via Campesina.

Vanhaute, Eric. 2011. "From Famine to Food Crisis: What History Can Teach Us about Local and Global Subsistence Crises." Journal of Peasant Studies 38 (1): 47-65.

Vasilikiotis, Christos. 2010. "Can Organic Farming 'Feed the World'?" In Agroecology and Sustainable Food Systems. Oakland: Food First, Institute for Food and Development Policy.

Vía Campesina, La. 2010. "Sustainable Peasant and Family Farm Agriculture Can Feed the World.” La Vía Campesina.

Victor, Peter A. 2008. Managing Without Growth: Slower by Design, Not Disaster, Advances in Ecological Economics. Cheltenham, UK; Northampton, MA: Edward Elgar.

Viet, Nguyen Van. 2011. "Climate Change and Agricultural Production in Vietnam." In Climate Change Management: Economic, Social and Political Elements of Climate Change, edited by W. Leal Filho. Berlin / Heidelberg: DEU: Springer.

Viet Nam Business News. 2010. "Fertiliser Prices Rising Fast." April 20.

Viet Nam News. 2011. "Climate Change Script Reflects Harsh Realities.” September 8.

Vietnam Peasant Association. 2010. "Cat dien nong thon trien mien: San xuat lay lat, nguoi song quay quat" [Continuous Blackout in the Countryside: Production Dropping, Humans Suffering]. Nien giam Nong nghiep - Thuc pham, May 15.

VietNamNet Bridge. 2009. "UN Says China Dams Threaten Water Supplies to Mekong Delta Farmers." May 25.

—. 2010. "Activists Argue That "Dams Will Kill the Mighty Mekong." February 9. Viet, Nguyen Van. 2011. "Climate Change and Agricultural Production in Vietnam." In Climate Change Management: Economic, Social and Political Elements of Climate Change, edited by W. Leal Filho. Berlin / Heidelberg: DEU: Springer.

Vogel, Coleen, and Karen O'Brien. 2004. "Vulnerability and Global Environmental Change: Rhetoric and Reality." AVISO (13).

VOV News. 2009. "Nuoc ngam tai Đong bang sông Cuu Long tut giam manh" [Underground Water in the Mekong Delta Has Depleted Significantly]. April 19.

Weis, Anthony. 2007. The Global Food Economy: The Battle for the Future of Farming. London; New York: Zed Books; Halifax: Fernwood Pub.

- 2010. "The Accelerating Biophysical Contradictions of Industrial Capitalist Agriculture." Journal of Agrarian Change 10 (3): 315-41.

Wiegersma, Nancy. 1988. Vietnam: Peasant Land, Peasant Revolution: Patriarchy and Collectivity in the Rural Economy. Hong Kong: MacMillan Press.

Woodhouse, Philip. 2010. "Beyond Industrial Agriculture? Some Questions about Farm Size, Productivity and Sustainability." Journal of Agrarian Change 10 (3): 437 53.

World Bank. 2010. World Development Report 2010: Development and Climate Change. The World Bank.

Wright, Julia. 2009. Sustainable Agriculture and Food security in an Era of Oil Scarcity: Lessons from Cuba. London: Earthscan.

Young, Kenneth B., Eric J. Wailes, Gail L. Cramer, and Tri Khiem Nguyen. 2002. Vietnam's Rice Economy: Developments and Prospects. University of Arkansas Research Report 968. 
Young, Oran R., Frans Berkhout, Gilberto C. Gallopin, Marco A. Janssen, Elinor Ostrom, and Sander van der Leeuw. 2006. "The Globalization of Socio-ecological Systems: An Agenda for Scientific Research." Global Environmental Change 16 (3): 304-16.

Yu, Bingxin, Tingju Zhu, Clemens Breisinger, and Nguyen Manh Hai. 2010. "Impacts of Climate Change on Agriculture and Policy Options for Adaptation: The Case of Vietnam." IFPRI Discussion Paper 01015. Washington, DC: IFPRI.

François Fortier is assistant professor at the School of International Development and Global Studies, University of Ottawa, Canada. He studies and teaches on the political economy of climate change, examining among other issues the dynamics of power that shape global and national adaptation strategies. Those include the dominant responses of green capitalism, but also the rise of contesting alternatives such as the food sovereignty and degrowth movements. Fortier can be reached at ffortier@uottawa.ca. 